\title{
Research on Ideological and Political Teaching Mode in Professional Courses in Colleges
}

\author{
Zhinuo Li ${ }^{1}$ Keliang Jia ${ }^{2, *}$ \\ ${ }^{1}$ College of Marxism, Shandong University of Finance and Economics, Jinan, China \\ ${ }^{2}$ School of Management Science and Engineering, Shandong, Shandong University of Finance and Economics, Jinan, \\ China \\ *Corresponding author. Email: sdjiakeliang@qq.com
}

\begin{abstract}
The paper analyses the connotation of ideological political education in professional courses, and then designs a teaching mode of professional courses from four aspects: excavating the ideological and political elements from the specialized courses, mode of integrating ideological and political education with professional course learning, mode of integrating ideological and political substances with Curriculum, and designing teaching methods with ideological political education. It can promote the construction and practice of professional courses teaching with ideological political education.
\end{abstract}

Keywords: Professional Courses, Course Teaching with Ideological Political Education, Teaching Mode

\section{INTRODUCTION}

In colleges, ideological and political theory curriculum is responsible for the education of students' world outlook, view on life and values, while professional courses are responsible for the education of basic knowledge, skills and the frontier development of related majors. To comprehensively promote ideological and political construction in professional courses, it has become the fundamental target of morality education and the key step to enhance the quality of personnel training. The implementation of ideological political education in professional course teaching is to take advantage of their basic position of professional curriculum teaching, to fully mine ideological and political substances from the knowledge and teaching procedure, and to consciously perform the education in the entire process of professional course teaching. The teaching process includes theoretical teaching, case teaching, course discussion, classroom management, course assignment, course management. Students' ideological level, political consciousness, morality and cultural literacy can be improved by educating students' professional knowledge and skills [1].

\section{RELATED WORKS}

It is a matter worthy of further discussion that to integrate and infiltrate ideological and political ideas into the construction of professional curriculum in colleges effectively and deeply. Course teaching with ideological political education is a brand-new view of education and curriculum. It is to reach mutual integration of ideological political education and professional courses [2]. In a word, course teaching with ideological political education is actually to radiate its content and idea into the professional courses, so as to realize an all-round education, and to promote all courses going together. It not only supports the talent training objectives of higher education in theory, but also provides an action guide to the research and implementation of ideological political teaching in practice.

Huang [3] fully mined ideological and political education substances hided in "new engineering" curriculum, and explored the development way by integrating knowledge system with ideological political education to cultivate students' all-round development. Wang et al. [4] grasped the key and difficult problems of ideological political teaching and its collaborative education, deeply analysed the influencing factors of collaborative education, scientifically constructed the long-term mechanism of collaborative education, and comprehensively explored the factors such as subject, object, mediator, environment and the relationship between them. Li et al. [5] thought that professional teachers should excavate the ideological and political 
substances, integrate them with professional curriculum to enhance their educational ability. Zhang [6] thought that professional teachers and ideological political education teachers should fully cooperate and learn from each other, to implement the requirements of the Ministry of Education. Wu et al. [7] explored blended teaching approach of ideological political education in "artificial intelligence and pattern recognition" course for computer majors, deeply explored ideological and political substances, integrated them with the typical cases of the course, so that students can feel the truth and edify feelings, and have a higher learning motivation.

\section{IDEOLOGICAL AND POLITICAL TEACHING MODE}

\subsection{Mining Ideological and Political Elements}

Contents of professional curriculum contain rich ideological and political elements: patriotism, socialist core values, professional ethics and work ethics, scientific spirit, professionalism, and spirit of the times, etc.
Patriotism: Patriotism education is a lifelong compulsory course for everyone. Ideological political education of professional curriculum needs to be integrated with patriotism firstly. Teachers can lead students to comprehend the professional development and leading technology of the major, make students realize the advantages and differences between China and other countries. This can cultivate students' national pride and cultural confidence, stimulate students' spirit of assiduous and serious study, and working hard, and cultivate college students' patriotism and ambition to serve the country.

The core values of Chinese socialism: A fine example has boundless power. Professional teachers in universities should be good at using the examples of experts or typical technologies in professional field to educate and guide students, so as to pass on the core values carried by examples and make students have emotional resonance and behavioural inspiration. What's more, it can lead students to comprehend and uphold excellent moral character of experts and scholars in pursuit of truth and patriotic dedication.

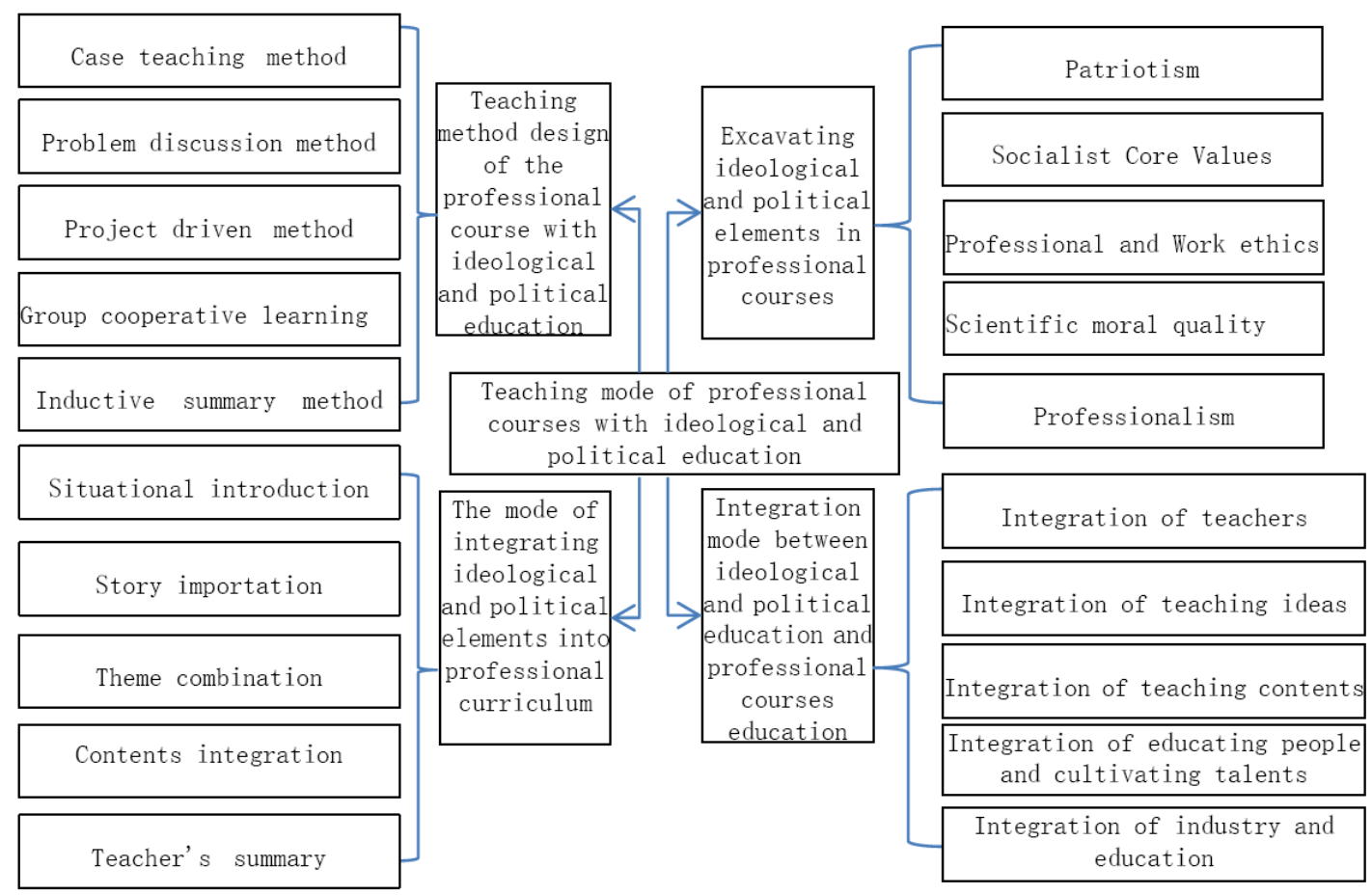

Figure 1 Framework of Teaching Mode

Professional and work Ethics: Professional teachers should impart relevant professional ethics to students purposefully and in a plan way. The paper discusses the values encountered in professional practice by means of scenario simulation and classroom discussion, and integrates professional ethics education into professional education, to guide students to correctly comprehend the possible ethical confusions and ethical consequences in professional learning and practice. The further imperceptibly and thoroughly understood professional ethics awareness and the requirements of the industrial norms will guide students to develop professional ethics awareness and comply with the industrial norms and professional ethics.

Scientific moral quality: Professional courses contain a variety of scientific thinking and methodology. The study, training, mastery and 
application of thinking methods are of great help to the formation of healthy scientific belief. College students must always follow the moral codes contained in scientific moral literacy, such as advocating science, seeking truth from facts, respecting knowledge, being brave in innovation, knowledge sharing, scientific cooperation, honesty and integrity, and social responsibility, which play a prominent part in the cultivation of their scientific moral literacy. Scientific thinking and methodology can not only be applied in professional fields and enhance professional ability, but also be transferred to social life, improve individual thinking and behaviour, and promote the formation of correct values. Through the education of scientific moral quality for college students, we can cultivate their spirits of loving science and advocating innovation.

Professionalism: Teachers' self-discipline is closely related to "dedication" in the socialist core values. Teachers are the best and the most direct ideological and political elements. They can infect students through their own professionalism and affect students' future professional behaviours.

\subsection{Mode of integrating ideological and political teaching with professional course teaching}

Ideological and political teaching integration mainly includes: integration of teachers, integration of teaching ideas, integration of teaching contents, integration of education and talent cultivation.

Integration of teachers: Professional teachers and ideological and political teachers should achieve cross professional cooperation. In teaching practice, educators who do not major in political will inevitably face many professional problems that cannot be overcome. To get the equal development of ideological political education with professional course education, it is essential for educators who do not major in political and ideological and political majors to cooperate. It not only enables the former master more scientific, systematic and effective ways of the education, but also enables the later to obtain more vivid materials through cooperation. What's more, it may even further explore the features of the education in diverse fields to form a synergistic effect. Students can naturally be affected by the sublimation of ideas, the enrichment of political knowledge and the improvement of theoretical level in the learning process of professional courses.

Integration of teaching ideas: "Teacher's role is to preach, to teach, and to solve puzzles". Professional course teachers should fully realize that their primary task is to "preach", to preach the socialist road, and to cultivate socialist successors. Teaching is to teach students professional knowledge. Solving puzzles means that teachers should not only explain the students' puzzles in their professional knowledge learning, but also explain their puzzles in their thoughts. In addition, teachers should fully realize the significance of the integration of preaching and teaching, and actively change teaching methods and improve teaching contents in practice.

Integration of teaching contents: Teachers need to extract rich ideological and political substances from content of specialized curriculum, and integrate them with professional courses. While receiving specialized knowledge, students can also receive ideological political education imperceptibly. They can learn how to study, think and understand.

Integration of educating people and cultivating talents: According to the core quality requirements and the characteristics and orientation of professional talents training, teachers need to clearly raise the general demands of "Curriculum ideological Political Education" of specialized courses and accurately design the training objectives and then form a systematic target system. In the professional talent training program, teachers should systematically and comprehensively reflect the demands, emphasize the education throughout whole teaching procedure, and infiltrate the substances into each course, to form a good pattern "There is ideological political education in every course, and every teacher can teach ideological political education".

Deep integration of industry and education: Extracurricular practice base connects classroom teaching and enterprise practice, which not only provides important practical teaching resources for university personnel training, but also provides an important base for "ideological political education". In the extracurricular practice base, practice can effectively improve students' professional and technical skills, so as to achieve the effect of applying what they have learned. At the same time, in the process of practice, "good reputation", "craftsman spirit" and other excellent corporate culture will have a profound impact on students.

\subsection{Mode of Integration Ideological and Political Elements into Curriculum}

Integration of ideological political education with specialized courses requires carefully design of each link. Some methods are as follows:

Situational introduction: In the classroom, teachers can create teaching situations to make students quickly comprehend lecture topics.

Story importation: The introduction of new courses can be combined with the stories related to the research theme. It is easy to stimulate students' resonance, and 
stimulate their learning motivation and sense of responsibility.

Theme combination: Teachers can combine some related philosophy in life with the course content to make the learning content easy to be understood.

Content integration: The deep integration of curriculum content can integrate ideological and political substances with professional content naturally.

Teacher's summary: Teachers can summarize the scientific outlook related to the course theme, which reflects the scientific research spirit of scientists' pursuit of truth, perseverance, bold and rigorous attitude etc.

\subsection{Teaching Methods in professional course}

Based on the characteristics of the course and teaching content, we should consider how to use appropriate methods, timely and appropriately embed the content of ideological political education, to achieve imperceptible and natural integration.

Case teaching method: Based on teaching objectives and contents, typical cases with rich substances of ideological political education are selected in case teaching. Knowledge points are integrated into the cases.

Problem discussion method: For the classic argumentative problems in the course, students can more systematically use the dialectics and epistemology methods learned in ideological and political course to understand and analyse them, which can lead students to understand and construct an exact scientific world opinion.

Project driven method: Taking some real problems as projects, students can acquire professional skills by completing projects. This process mainly helps students to develop a serious and responsible learning attitude, establish a sense of rules, strengthen their minds, and cultivate their enterprising spirit of bold exploration and craftsman spirit of hard working and scientific attitude of seeking truth and pragmatism.

Group cooperative learning method: In practice teaching, students explore project research with learning group as a unit. All team members work together to complete problem research of the project, discussion and communication, report writing. It can cultivate students' team spirit and collective concept, and enhance communication and help among students.

Inductive summary method: in the summary of classroom teaching, teachers can reveal some hidden ideological and political elements through summary and induction.

\section{CONCLUSION}

To realize knowledge imparting and value leading in professional courses is the main way to intensify the course development with ideological political education. Therefore, the paper designs the professional courses teaching mode with ideological political education from four aspects, hoping to push ahead the reformation and practice of ideological political education of professional courses. We should constantly explore, practice, feedback and achieve iterative improvement in the future.

\section{REFERENCES}

[1] Ye Lian, "The internal logic and practical path of the same direction of curriculum ideological and political education and quality education", University Education, 2020(3)121-123.

[2] GONG Lina, "The Effective Implementation Path of Ideological Political Education on Finance and Accounting Courses in Colleges in the New Era", Journal of Hubei Radio \& Television University, 41(2)(2021) 32-35.

[3] Huang Zewen, "The era implication and development route of ideological political education of "new engineering', Journal of Southwest University (Social Science Edition), 2021(3)162-168

[4] WANG Jingxin, ZHOU Ting, LIU Huibai, "The Problems and Countermeasures of Collaborative Education between Ideological Politics Course and Course Ideological Politics in Colleges and Universities", Journal of Xingyi Normal University for Nationalities, 2021(2)83-89.

[5] Li Wei, Wang Qin, Wang Yanfang, "The Path of Promoting Integrated Construction of 'Ideological Political Education through All Majors' and 'Ideological Political Education through All Curricula' under the Background of New Business", Journal of Beijing Union University, 35(2)( 2021) 33-39.

[6] Zhang Xiaoxiao, "The Integration of Ideological and political Curriculum' v.s Route Choice of Ideological Political Education in Classroom", Journal of Yanbian University (Social Sciences Edition), 54(3)(2021)79-85.

[7] WU Xiaogang, "Research on the Integration Mode of Ideology and Politics in Professional Courses Teaching - Taking Artificial Intelligence Course for Example", Journal of Xingyi Normal University for Nationalities, 2021(2) 90-92. 